\title{
ANALISIS AGROINDUSTRI LEMPUK DURIAN DI DESA SELATBARU KECAMATAN BANTAN KABUPATEN BENGKALIS
}

\author{
Agroindustry Analysis of Lempuk Durian \\ in Selatbaru Village Bantan District Bengkalis Regency
}

\author{
Dora Felicita Dongoran dan Sisca Vaulina \\ Fakultas Pertanian Universitas Islam Riau. \\ Jl. Kaharuddin Nasution 113, Pekanbaru 28284 Riau \\ Email: siscavaulina@agr.uir.ac.id \\ [Diterima: Juli 2019; Disetujui: Agustus 2019]
}

\begin{abstract}
Agroindustry is an activity of processing agricultural products to be semi-product or product that has economic value. The purpose of this study was to determine the characteristics of entrepreneurs and agroindustry business profiles of lempuk durian, the use of raw materials, supporting materials, labor, processing technology, and production processes of lempuk durian, the poduction costs, income, efficiency and added value of lempuk durian, and marketing of durian products. The study used survey methods located in Selatbaru Village, Bantan District, Bengkalis Regency, Riau Province. A total of 4 craffsmen was selected as respondents by the census. The data were analyzed by qualitative descriptive and quantitative descriptive approaches. The results showed that the lempuk durian craffsman averaged 47 years old, 12 years old education, 14 years of business experience, and 5 person of family member. Agroindustry profile of lempuk durian was a small-scale industry category. The use of raw materials consisted of durian meat and supporting materials such as sugar, firewood, plastic packing, bunch, string, label, isolation, solar, and gas cylinders. The average use of fixed costs was IDR 1,968,633 per production process, production costs was IDR 15,886,133 per production process, gross income was IDR 26,937,500 per production process and net income was IDR 11,051,367 per production process and RCR value was 1.70 with value-added IDR 51,016. The marketing of lempuk durian had two marketing channels.
\end{abstract}

Keywords: Lempuk Durian, Agroindustry, Value Added, Marketing

\begin{abstract}
ABSTRAK
Agroindustri adalah suatu kegiatan pemanfaatan hasil produksi pertanian menjadi produk olahan jadi atau setengah jadi yang bernilai ekonomi. Tujuan penelitian untuk mengetahui karakteristik pengusaha dan profil usaha agroindustri lempuk durian, penggunaan bahan baku, bahan penunjang, penggunaan tenaga kerja, teknologi pengolahan serta proses produksi agroindustri lempuk durian, besarnya biaya produksi, pendapatan, efisiensi dan nilai tambah agroindustri lempuk durian dan pemasaran hasil produk olahan durian. Penelitian menggunakan metode survey, di Desa Selatbaru Kecamatan Bantan Kabupaten Bengkalis Provinsi Riau. Responden pengusaha diambil dengan cara sensus dengan jumlah 4 pengusaha, data dianalisis dengan deskriptif kualitatif dan deskriptif kuantitatif. Hasil penelitian menunjukkan bahwa (1) Karakteristik pengusaha lempuk durian rata-rata berumur 47 tahun, lama pendidikan pengusaha 12 tahun, pengalaman berusaha 14 tahun dan jumlah tanggungan keluarga 5 jiwa. Profil usaha agroindustri lempuk durian berbentuk skala industri kecil. (2) Rata-rata penggunaan bahan baku berupa daging durian $225 \mathrm{~kg} /$ proses produksi, penggunaan bahan penunjang berupa: gula $56,25 \mathrm{~kg} /$ proses produksi, kayu bakar 45 ikat, plastik packing (ukuran 150 gram $1 \mathrm{~kg}, 200$ gram $2 \mathrm{~kg}, 250$ gram $2 \mathrm{~kg}, 400$ gram $1 \mathrm{~kg}, 500$ gram $1,75 \mathrm{~kg}$, dan ukuran $1 \mathrm{~kg}$ $1,25 \mathrm{~kg}$ ), upih 11,75 ikat, tali 1 gulung, label $1 \mathrm{rim}$, isolasi 2,5 gulungan, solar 4,5 liter, menghabiskan 8,5 tabung gas ukuran $3 \mathrm{~kg}$. (3) Rata-rata penggunaan biaya tetap Rp. 1.968.633/proses produksi, biaya produksi Rp 15.886.133/proses produksi. Pendapatan kotor Rp 26.937.500/proses produksi dan pendapatan bersih Rp 11.051.367/proses produksi. Nilai RCR 1,70, dengan nilai tambah Rp 51.016. (4) Pemasaran produk lempuk durian memiliki dua saluran pemasaran.
\end{abstract}

Kata kunci: Lempuk Durian, Agroindustri, Nilai Tambah, Pemasaran 


\section{PENDAHULUAN}

Bengkalis merupakan salah satu kabupaten yang berada di Propinsi Riau. Kabupaten ini kaya akan hasil pertanian, salah satunya adalah buah durian. Produksi durian di Kabupaten Bengkalis selama lima tahun terakhir (tahun 2013-2017) mengalami peningkatan $57,89 \%$. Melimpahnya hasil panen durian tersebut, membuat buah durian segar tidak semuanya habis dikonsumsi. Selain itu, Aldy dan Prayoga (2019), produk dengan bahan segar memiliki umur simpan yang relatif singkat. Menurut Rachmat (2013), kondisi ini menjadi tidak menguntungkan untuk suatu usaha karena hilangnya nilai tambah produk.

Buah durian merupakan salah satu produk pertanian yang bisa ditingkatkan nilai tambahnya. Di Kabupaten Bengkalis, produk olahan buah durian berupa dodol; selai; tempoyak; ketan talam; pengat; lempuk; wajik; kue talam; dan pancake. Jenis jajanan yang menjadi ciri khas kabupaten ini adalah lempuk durian. Lempuk durian menjadi salah satu oleh-oleh khas dari Bengkalis yang banyak digemari dan mudah ditemui di gerai-gerai oleh-oleh.

Masyarakat Desa Selatbaru Kecamatan Bantan mengolah buah durian menjadi lempuk durian sebagai usaha untuk meningkatkan pendapatan mereka. Dengan demikian, banyak bermunculan agroindustri di desa tersebut. Pengusaha agroindustri olahan durian yang memiliki merek dagang di Desa Selatbaru dapat dilihat pada Tabel 1 .

Tabel 1. Pengusahan Agroindustri Lempuk Durian yang Memiliki Merek Dagang di Desa Selatbaru, Kecamatan Bantan, Tahun 2019

\begin{tabular}{clll}
\hline No & \multicolumn{1}{c}{ Nama Pengusaha } & \multicolumn{1}{c}{ Alamat } & \multicolumn{1}{c}{ Merek Dagang } \\
\hline 1 & Selamat (Ahok) & Jl. Soekarno Hatta & Citra Rasa \\
2 & Cung Lai & Jl. Soekarno Hatta & Mawar dan Yanti \\
3 & Agus Sunarno & Jl. Mokhtar & Cik Mas Ayu \\
4 & Sujaini & Jl. Pelajar & Frands Family \\
\hline
\end{tabular}

Sumber: Kantor Desa Selatbaru, 2019 (Diolah)

Berdasarkan Tabel 1 diperoleh informasi bahwa pengusaha lempuk durian yang memiliki merek dagang terdapat empat pengusaha. Namun pada saat musim durian, masyarakat Desa Selatbaru memproduksi olahan durian secara dadakan. Hal ini disebabkan karena ketersediaan bahan baku yang berlimpah, buah durian tidak dapat bertahan lama, tidak habis dikonsumsi langsung dan harga yang tidak bisa diprediksi.

Tujuan penelitian ini adalah untuk mengetahui: (1) Bagaimana karakteristik pengusaha dan profil usaha agroindustri lempuk durian di Desa Selatbaru Kecamatan Bantan Kabupaten Bengkalis, (2) Bagaimana penggunaan bahan baku, bahan penunjang, penggunaan tenaga kerja, teknologi pengolahan serta proses produksi lempuk durian di Desa Selatbaru Kecamatan Bantan Kabupaten Bengkalis, (3) Berapa biaya produksi, pendapatan, efisiensi dan nilai tambah agroindustri lempuk durian di Desa Selatbaru Kecamatan Bantan Kabupaten Bengkalis, (4) Bagaimana pemasaran produk lempuk durian.

\section{METODE PENELITIAN}

Penelitian ini menggunakan metode survei yang dilaksanakan di Desa Selatbaru
Kecamatan Bantan Kabupaten Bengkalis Provinsi Riau. Pemilihan lokasi penelitian ini didasarkan atas pertimbangan bahwa di daerah ini terdapat banyak produksi durian dan pengusaha agroindustri lempuk durian. Penelitian ini dilaksanakan selama 6 (enam) bulan yang dimulai dari bulan Maret - Juli 2019.

Teknik pengambilan responden dalam penelitian ini menggunakan teknik sensus dengan mengambil 4 (empat) pengusaha lempuk durian. Jumlah tersebut diambil berdasarkan pada kontinuitas berproduksi dan produk mereka sudah terkenal. Nama usaha agroindustri olahan durian tersebut yaitu Citra Rasa, Mawar \& Yanti, Cik Mas Ayu, serta Frands Family. Data yang dikumpulkan terdiri dari data primer dan data skunder.

\section{ANALISIS DATA}

\section{Karakteristik Pengusaha dan Profil Usaha Agroindustri Lempuk Durian}

Mengetahui karakteristik pengusaha dan profil usaha agroindustri lempuk durian dianalisis secara deskriptif kualitatif. Karakteristik pengusaha lempuk durian yang dianalisis meliputi: umur, tingkat pendidikan, pengalaman usaha, jumlah tanggungan 
keluarga. Selanjutnya, profil usaha agroindustri lempuk durian meliputi sejarah usaha, skala usaha, modal usaha, dan jumlah tenaga kerja.

\section{Penggunaan Bahan Baku, Bahan Penunjang, Penggunaan Tenaga Kerja, Teknologi Pengolahan, Serta Proses Produksi Agroindustri Lempuk Durian \\ Penggunaan bahan baku, bahan penunjang, penggunaan tenaga kerja, teknologi pengolahan serta proses produksi agroindusti lempuk durian, dianalisis dengan deskriptif kuantitatif dan deskriptif kualitatif. Bahan baku yang digunakan dalam pembuatan lempuk yaitu daging durian, penggunaan bahan penunjang (gula, kayu bakar, gas, plastik packing, dan isolasi).}

Biaya Produksi, Pendapatan, Efisiensi Usaha, dan Nilai Tambah Agroindustri Lempuk Durian

\section{a). Biaya Usaha Agroindustri Lempuk \\ Durian}

Biaya agroindustri durian adalah semua biaya yang dikeluarkan oleh pengusaha dalam satu kali proses produksi. Biaya produksi terdiri dari biaya tetap dan biaya variabel. Menghitung besarnya biaya produksi dapat dihitung menggunakan rumus menurut (Soekartawi, 2002):

Rumus yang digunakan sebagai berikut:

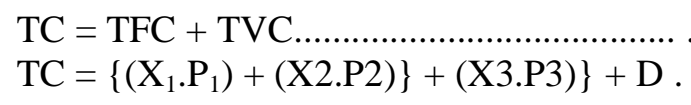

Keterangan:

\begin{tabular}{|c|c|}
\hline $\mathrm{C}$ & $=\begin{array}{l}\text { Total cost }(\text { total biaya) }(\mathrm{Rp} / \mathrm{proses} \\
\text { produksi) }\end{array}$ \\
\hline TFC & $\begin{aligned}= & \text { Total fixed cost (total biaya tetap) } \\
& (\mathrm{Rp} / \mathrm{proses} \text { produksi) }\end{aligned}$ \\
\hline TVC & $\begin{aligned}= & \text { Total variable cost (total biaya } \\
& \text { variabel) }(\mathrm{Rp} / \mathrm{proses} \text { produksi). }\end{aligned}$ \\
\hline $\mathrm{X}_{1}$ & $\begin{aligned}= & \text { Jumlah penggunaan bahan baku } \\
& (\mathrm{Kg} / \text { Proses produksi })\end{aligned}$ \\
\hline $\mathrm{X}_{2}$ & $\begin{aligned}= & \text { Jumlah penggunaan bahan penunjang } \\
& (\mathrm{Kg} / \text { Proses produksi })\end{aligned}$ \\
\hline$X_{3}$ & $=\underset{\text { produksi) }}{\text { Jumlah Biaya Tetap }(\mathrm{Rp} / \text { Proses }}$ \\
\hline $\mathrm{P}_{1}$ & $=\begin{array}{l}\text { Harga bahan baku }(\mathrm{Kg} / \text { Proses } \\
\text { produksi })\end{array}$ \\
\hline $\mathrm{P}_{2}$ & $\begin{array}{l}=\text { Harga bahan penunjang }(\mathrm{Rp} / \text { Proses } \\
\text { produksi })\end{array}$ \\
\hline $\mathrm{P}_{3}$ & $\begin{array}{l}=\text { Harga biaya tetap }(\mathrm{Rp} / \text { Proses } \\
\text { Produksi) }\end{array}$ \\
\hline & Jilai Penyusutan (Rp) \\
\hline
\end{tabular}

Peralatan yang digunakan pada usaha agroindustri lempuk durian umumnya tidak habis dipakai dalam satu kali periode produksi atau memiliki umur ekonomis lebih dari satu tahun. Oleh karena itu, peralatan yang digunakan hanya dihitung sebagai komponen biaya produksi yang berupa nilai penyusutan peralatannya. Untuk mengetahui besarnya biaya penyusutan pada alat-alat pertanian dengan menggunakan metode garis lurus yang dikemukakan oleh Hernanto (1996) yaitu:

$\mathrm{D}=\frac{\mathrm{NB}-\mathrm{NS}}{\mathrm{UE}}$

Keterangan:

$\mathrm{D} \quad=$ Penyusutan Alat (Rp/proses produksi)

NB = Nilai Beli (Rp/unit/tahun)

NS = Nilai Sisa dari harga beli

(Rp/unit/tahun)

UE = Umur Ekonomi (Tahun)

\section{b). Pendapatan kotor}

Pendapatan kotor yang diterima oleh pengrajin agroindustri lempuk durian diperoleh dengan cara mengkalikan antara jumlah produksi dengan harga yang berlaku, dengan rumus menurut Soekartawi (1995):

$\mathrm{TR}=\mathrm{Q} \cdot \mathrm{Pq}$

Keterangan:

$\mathrm{TR}=$ Pendapatan Kotor $(\mathrm{Rp} /$ proses produksi)

$\mathrm{Q}=$ Jumlah Produksi Lempuk Durian (Kg/proses produksi)

$\mathrm{Pq}=$ Harga Produksi Lempuk Durian (Kg/proses produksi)

\section{c). Pendapatan Bersih}

Menganalisis pendapatan bersih usaha agroindustri lempuk durian dapat digunakan rumus menurut Soekartawi (2000):

$\pi=\mathrm{TR}-\mathrm{TC}$

Keterangan:

$\pi \quad=$ Keuntungan $(\mathrm{Rp} /$ Proses Produksi)

$\mathrm{TR}=$ Pendapatan Kotor (Rp/Proses Produksi)

$\mathrm{TC}=$ Total Biaya $(\mathrm{Rp} /$ Proses produksi $)$

\section{d). Efisiensi Usaha Lempuk Durian}

Efisiensi usaha agroindustri lempuk durian dapat dihitung dari perbandingan antara besarnya nilai penerimaan dan biaya dari usaha agroindustri lempuk durian yaitu menggunakan Return Cost Ratio (RCR) dengan rumus menurut Hernanto (1991): 
$\mathrm{RCR}=\frac{\mathrm{TR}}{\mathrm{TC}}$

Keterangan:

$\mathrm{RCR}=$ Return Cost Ratio (Rp/proses produksi)

TR = Pendapatan Kotor (Total Revenue)(Rp/proses produksi)

$\mathrm{TC}=$ Total Biaya Produksi (Total Cost)

(Rp/proses produksi)

Dengan Kriteria:

RCR > 1 : Agroindustri lempuk durian yang dilakukan efisien dan menguntungkan serta layak untuk dikembangkan

RCR < 1 : Agroindustri lempuk durian yang dilakukan tidak efisien (rugi) serta tidak layak untuk dikembangkan
$\mathrm{RCR}=1: \quad$ Agroindustri lempuk durian yang dilakukan berada pada titik impas (baik modal / tidak untung dan tidak rugi)

\section{e). Nilai Tambah}

Mengetahui besarnya nilai tambah dan keuntungan agroindustri lempuk durian pada penelitian ini, dilakukan menggunakan analisis metode Hayami. Menurut Hayami dalam Dewi dkk (2013), nilai tambah merupakan selisih nilai komoditi karena adanya perlakuan pada tahap tertentu yang dikurangi dengan pengeluaran yang dilakukan selama proses tersebut. Variabel-variabel metode Hayami dapat dilihat pada Tabel 2.

Tabel 2. Metode Perhitungan Nilai Tambah (Value Added) Hayami.

\begin{tabular}{|c|c|c|}
\hline No & 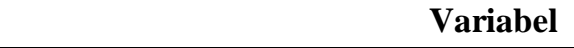 & Nilai \\
\hline \multicolumn{3}{|c|}{ I. Output, Input, dan Harga } \\
\hline 1. & Output (Kg) & (1) \\
\hline 2. & Input $(\mathrm{Kg})$ & (2) \\
\hline 3. & Tenaga kerja (HOK) & (3) \\
\hline 4. & Faktor konversi & $(4)=(1) /(2)$ \\
\hline 5. & Koefisien Tenaga Kerja (HOK/Kg) & $(5)=(3) /(2)$ \\
\hline 6. & Harga output (Kg) & (6) \\
\hline & Upah tenaga kerja (Rp/HOK) & (7) \\
\hline \multicolumn{3}{|c|}{ II. Pendapatan dan Keuntungan } \\
\hline 8. & Harga bahan baku (Rp/Kg) & $(8)$ \\
\hline 9. & Sumbangan input lain (Rp/Kg output) & (9) \\
\hline 10. & Nilai output (Rp/Kg/Output) & $(10)=(4) \times(6)$ \\
\hline \multirow[t]{2}{*}{11.} & a.Nilai tambah $(\mathrm{Rp} / \mathrm{Kg})$ & $(11 a)=(10)-(8)-(9)$ \\
\hline & b.Rasio nilai tambah (\%) & $(11 b)=(11 a) /(10) \times 100 \%$ \\
\hline & a.Pendapatan TK langsung (Rp/Kg) & $(12 a)=(5) \times(7)$ \\
\hline & b.Pangsa tenaga kerja (\%) & $(12 b)=(12 a) /(11 a) \times 100 \%$ \\
\hline \multirow[t]{2}{*}{13.} & a.Keuntungan $(\mathrm{Rp} / \mathrm{Kg})$ & $(13 a)=(11 a)-(12 a)$ \\
\hline & b.Tingkat Keuntungan (\%) & $(13 b)=(13 a) /(11 a) \times 100 \%$ \\
\hline \multicolumn{3}{|c|}{ III. Balas Jasa Pemilik Faktor Produksi } \\
\hline \multirow[t]{4}{*}{14.} & Margin (Rp/Kg) & $(14)=(10)-(8)$ \\
\hline & a. Pendapatan tenaga kerja $(\%)$ & $(14 a)=(12 a) /(14) \times 100 \%$ \\
\hline & b.Sumbangan input lain (\%) & $(14 b)=(9) /(14) \times 100 \%$ \\
\hline & c.Keuntungan pengusaha $(\%)$ & $(14 c)=(13 a) /(14) \times 100 \%$ \\
\hline
\end{tabular}

Sumber: Sudiyono (2001)

\section{Pemasaran Hasil Produk Lempuk Durian}

Pemasaran hasil produksi olahan durian dapat dilihat kemana saja produk telah dipasarkan. Dalam penelitian ini, pemasaran hasil lempuk durian dilihat dari saluran pemasarannya. Saluran pemasaran merupakan suatu proses yang dilewati produk hingga sampai ke tangan konsumen sehingga dapat dimanfaatkan atau digunakan. Saluran pemasaran dianalisa dengan menggunakan analisi deskriptif kualitatif yakni memaparkan dalam bentuk deskripsi saluran pemasaran hasil lempuk durian dan diinterpretasikan dalam bentuk skema atau bagan.

\section{HASIL DAN PEMBAHASAN}

\section{Potensi Pengembangan Usaha Lempuk Durian di Kecamatan Bantan}

Durian (Durio zibethinus) merupakan salah satu tumbuhan tropis asli Asia Tenggara dan populer sebagai raja buah (Feng et al. 2016). Kecamatan Bantan adalah salah satu tempat yang memiliki potensi yang sangat besar terhadap produksi durian. Hampir setiap 
warga memiliki pohon durian, maka dari itu masyarakat setempat mengolah durian menjadi berbagai macam olahan.

Di daerah penelitian prospek adanya potensi pengembangan agribisnis mengolah durian yang cukup menjanjikan, terlihat dari meningkatnya minat masyarakat terhadap durian dalam bentuk buah segar maupun dalam bentuk olahan. Dilihat dari segi bisnis, pengolahan durian sangat menguntungkan, dikarenakan dalam kegiatan pengolahan tidak memerlukan bahan yang langka, teknologi budidaya yang mudah dipelajari dan kegagalan dalam usaha yang relatif rendah. Salah satu daerah yang melakukan kegiatan agroindustri olahan durian di Kecamatan Bantan adalah Desa Selatbaru. Di desa tersebut terdapat 4 pengusaha yang mengolah buah durian segar menjadi Lempuk.

Usaha lempuk durian di Desa Selatbaru Kecamatan Bantan Kabupaten Bengkalis awalnya hanya dilakukan oleh pengusaha 1 yang mengenalkan lempuk pada masyarakat setempat. Melihat keadaan di lapangan ternyata pada zaman tersebut hanya masyarakat Tionghoa yang melakukan pengolahan dan kemudian diikuti oleh pengusaha lainnya. Maka timbullah pengusaha 3 dan pengusaha 4 sebagai masyarakat pribumi yang ikut mengolah durian segar menjadi lempuk.

\section{Karakteristik Pengusaha dan Profil Usaha Lempuk Durian}

Pengusaha atau tenaga kerja adalah pelaku utama dalam mengelola agroindustri lempuk durian. Adapun karakteristik pengusaha yang dibahas pada penelitian ini yakni: umur, tingkat pendidikan, pengalaman berusaha, dan jumlah tanggungan. Karakteristik tersebut bisa dilihat pada Tabel 3.

Tabel 3. Karakteristik Pengusaha Lempuk Durian di Desa Selatbaru Kecamatan Bantan Kabupaten Bengkalis, Tahun 2019

\begin{tabular}{|c|c|c|c|c|c|c|c|c|c|}
\hline \multirow[t]{2}{*}{$\begin{array}{l}N \\
\mathrm{O}\end{array}$} & \multirow[t]{2}{*}{ Pengusaha } & \multicolumn{2}{|c|}{ Umur } & \multicolumn{2}{|c|}{ Pendidikan } & \multicolumn{2}{|c|}{ Pengalaman Usaha } & \multicolumn{2}{|c|}{$\begin{array}{c}\text { Jumlah } \\
\text { Tanggungan } \\
\text { Keluarga } \\
\end{array}$} \\
\hline & & Tahun & $\%$ & Tahun & $\%$ & Tahun & $\%$ & Jiwa & $\%$ \\
\hline 1 & Pengusaha 1 & 45 & 24,06 & 12 & 26,67 & 20 & 36,36 & 4 & 23,53 \\
\hline 2 & Pengusaha 2 & 40 & 21,39 & 12 & 26,67 & 10 & 18,18 & 5 & 29,41 \\
\hline 3 & Pengusaha 3 & 50 & 26,74 & 9 & 20,00 & 15 & 27,28 & 4 & 23,53 \\
\hline 4 & Pengusaha 4 & 52 & 27,81 & 12 & 26,66 & 10 & 18,18 & 4 & 23,53 \\
\hline \multicolumn{2}{|c|}{ Jumlah } & 187 & 100,00 & 45 & 100,00 & 55 & 100,00 & 17 & 100,00 \\
\hline \multicolumn{2}{|c|}{ Rata-Rata } & \multicolumn{2}{|c|}{46,75} & \multicolumn{2}{|c|}{11,25} & \multicolumn{2}{|c|}{13,75} & \multicolumn{2}{|c|}{4,25} \\
\hline
\end{tabular}

Berdasarkan Tabel 3, dapat diuraikan bahwa rata rata umur pengusaha yakni 46,75 tahun (47 tahun). Rata-rata pendidikan pengusaha lempuk durian selama 11,25 tahun (12 tahun) setara tamat SMA (Sekolah Menengah Atas). Pengalaman usaha agroindustri lempuk durian rata-rata pengusaha sudah memiliki pengalaman yaitu selama 13,75 tahun (14 tahun). Rata-rata jumlah tanggungan yang harus di tanggung oleh pengusaha adalah sebanyak 4,25 jiwa ( 5 jiwa).

\section{Profil Usaha Lempuk Durian}

Profil usaha lempuk durian merupakan gambaran umum mengenai kondisi usaha yang sedang dijalankan oleh seorang pengusaha. Profil usaha dalam penelitian ini mengenai (1) sejarah usaha; (2) skala usaha; (3) permodalan, dan (4) jumlah tenaga kerja.

\section{1). Sejarah Usaha}

Usaha lempuk durian yang dijalankan oleh Bapak Cung Lai (Pengusaha 1) ini berawal dari adanya ketersediaan bahan baku yang banyak, kemudian tidak habis untuk di konsumsi begitu saja. Kemudian, Bapak Cung Lai berinisiatif untuk membuka pengolahan durian menjadi lempuk. Diharapkan melalui kegiatan pengolahan durian segar menjadi lempuk dapat memberikan nilai tambah bagi pengusaha dan menimbulkan kegiatan ekonomi dalam penggunaan tenaga kerja dalam usaha yang dijalankan.

Bapak Selamat (Pengusaha 2) dan bapak Suzaini (Pengusaha 4) juga melakukan usaha olahan durian karena ketersediaan bahan baku yang melimpah. Sedangkan bapak Agus Sunarno (Pengusaha 3) dahulunya pernah menjadi pekerja disalah satu industri pengolahan durian, ilmu yang didapat selama ia bekerja inilah yang menjadi bekal ilmu untuk menerapkannya pada usahanya sendiri, selain dari itu ia juga mendapat dorongan untuk menjalankan usaha olahan durian karena 
kebanyakan pengusaha yang melakukan usaha olahan durian dan menguasai pasar adalah orang Tionghoa. Hal inilah yang menjadi dorongan bapak Agus Sunarno menunjukkan kemampuannya sebagai masyarakat pribumi. Walau masalah yang dihadapi cukup banyak mulai dari masalah tekstur dan rasa yang dihasilkan belum sesuai selera konsumen. Namun beliau tidak pernah menyerah hingga akhirnya produk lempuk durian miliknya diminati banyak masyarakat.

\section{2). Skala Usaha}

Usaha yang dijalankan oleh 4 pengusaha tersebut sudah cukup lama. Usaha ini berbentuk indutri kecil yang memanfaatkan bahan baku yang tersedia. Pemanfaatan bahan

baku yang melimpah dilakukan kegiatan mulai dari kegiatan pengumpulan bahan baku, pengolahannya sampai dengan pemasaran.

\section{3). Permodalan}

Usaha agribisnis yang dijalankan oleh pengusaha di Desa Selatbaru Kecamatan Bantan Kabupaten Bengkalis adalah usaha mandiri atau dengan modal sendiri. Melalui skala usaha maka usaha ini merupakan usaha kecil. Dilihat dari segi agribisnis lempuk durian menjanjikan untuk terus dikembangkan, dikarenakan adanya permintaan lempuk durian yang terus menerus. Modal yang dimiliki oleh pengusaha secara rinci dapat dilihat pada Tabel 4.

Tabel 4. Modal Awal yang dimiliki Pengusaha lempuk Durian di Desa Selatbaru Kecamatan Bantan Kabupaten Bengkalis.

\begin{tabular}{clccc}
\hline \multirow{2}{*}{ No } & \multirow{2}{*}{ Pengusaha } & $\mathrm{Rp}$ & Modal Awal & \multirow{2}{*}{ Sumber Modal } \\
\cline { 3 - 4 } & Pengusaha 1 & 500.000 .000 & 31,75 & Pribadi \\
2 & Pengusaha 2 & 425.000 .000 & 26,98 & Pribadi \\
3 & Pengusaha 3 & 350.000 .000 & 22,22 & Pribadi \\
4 & Pengusaha 4 & 300.000 .000 & 19,05 & Pribadi \\
\hline Jumlah & 1.575 .000 .000 & 100,00 & Pribadi \\
\hline \multicolumn{2}{l}{ Rata-Rata } & 393.750 .000 & & Pribadi \\
\hline
\end{tabular}

Pada Tabel 4 dapat dilihat bahwa jumlah modal awal yang dikeuarkan oleh pengusaha lempuk Durian di Kecamatan Bantan Kabupaten Bengkalis adalah sebesar Rp 1.575.000.000. dengan rata-rata $\mathrm{Rp}$ 393.750.000 dengan modal terbanyak yakni Rp $500.000 .000 \quad(31,75 \%)$ dan biaya modal terendah yakni Rp 300.000.000 (19,05\%). Modal sangat mempengaruhi kapasitas yang bisa kita penuhi dalam melakukan proses produksi. Semakin besar modal, maka semakin banyak pula kapasitas produksi dan sebaiknya.

4) Jumlah Tenaga Kerja

Peningkatan produksi dan pendapatan usaha agroindustri salah satu faktor yang mempengaruhinya yaitu tenaga kerja. Dalam kegiatan proses produksi pelaku utama dan terkait secara langsung adalah tenaga kerja, baik tenaga kerja dalam keluarga maupun luar keluaga.

Tabel 5. Penggunaan Tenaga Kerja Lempuk Durian di Desa Selatbaru Kecamatan Bantan Kabupaten Bengkalis, Tahun 2019

\begin{tabular}{|c|c|c|c|c|c|c|c|}
\hline & \multirow[b]{2}{*}{ Pengusaha } & \multicolumn{4}{|c|}{ Tenaga Kerja } & \multirow{2}{*}{\multicolumn{2}{|c|}{ Jumlah (Orang) }} \\
\hline & & TKDK & $\%$ & TKLK & $\%$ & & \\
\hline No & Pengusaha 1 & 0 & - & 10 & 34,48 & \multicolumn{2}{|c|}{10} \\
\hline 2 & Pengusaha 2 & 3 & 27,28 & 7 & 24,14 & \multicolumn{2}{|c|}{10} \\
\hline 3 & Pengusaha 3 & 4 & 36,36 & 6 & 20,69 & \multicolumn{2}{|c|}{10} \\
\hline \multirow[t]{2}{*}{4} & Pengusaha 4 & 4 & 36,36 & 6 & 20,69 & \multicolumn{2}{|c|}{10} \\
\hline & Jumlah & 11 & 100,00 & 29 & 100,00 & \multicolumn{2}{|c|}{40} \\
\hline \multicolumn{2}{|r|}{ Rata-Rata } & \multicolumn{2}{|c|}{2,75} & \multicolumn{2}{|c|}{7,25} & \multicolumn{2}{|c|}{10} \\
\hline \multirow{2}{*}{\multicolumn{2}{|c|}{$\begin{array}{l}\text { Tabel } 5 \\
\text { penggunaan tenaga } \\
\text { dengan rata-rata } 2,75 \\
\text { dengan jumah paling } \\
(27,28 \% \text { ) dan yang la } \\
\text { Sedangkan untuk ter } \\
\text { rata-rata penggunaann }\end{array}$}} & \multirow{2}{*}{\multicolumn{2}{|c|}{$\begin{array}{l}\text { untuk } \\
\text { keluarga } \\
\text { ga kerja) } \\
3 \text { orang } \\
36,36 \%) \text {. } \\
\text { keluarga } \\
8 \text { orang) }\end{array}$}} & \multicolumn{4}{|c|}{$\begin{array}{l}\text { dengan jumlah paling sedikit yakni } 6 \text { orang } \\
(20,69 \%) \text { dan yang paling banyak adalah } 10 \\
\text { orang }(34,48 \%) \text {. }\end{array}$} \\
\hline & & & & $\begin{array}{l}\text { Penggunaan } \\
\text { Penunjang, } \\
\text { Teknologi } \\
\text { Produksi }\end{array}$ & $\begin{array}{l}\text { Bahan } \\
\text { Penggunaan } \\
\text { Pengolahan }\end{array}$ & $\begin{array}{l}\text { Baku, } \\
\text { Tenaga } \\
\text { serta }\end{array}$ & $\begin{array}{l}\text { Bahan } \\
\text { Kerja, } \\
\text { Proses }\end{array}$ \\
\hline
\end{tabular}


a. Penggunaan Bahan Baku

Bahan baku yang digunakan dalam usaha pembuatan lempuk durian yaitu daging buah durian segar. Pengusaha memperoleh bahan baku dengan cara membelinya ke masyarakat dengan pembeli perantara. Apabila daerah tersebut tidak musim panen maka pengusaha mendatangkan buah durian segar dari luar daerah dengan harga beli sudah termasuk pengiriman. Buah durian dari luar mempunyai perbedaan dengan buah durian lokal mulai dari bentuknya, kadar air, dan rasa. Tentunya dapat mempengaruhi cita rasa yang dihasilkan pada lempuk.

Berdasarkan Tabel 6 dapat dilihat bahwa rata-rata penggunaan buah durian untuk satu kali proses produksi yaitu 2.250 buah dengan jumlah terbanyak yakni 3.000 buah $(33,33 \%)$, dan yang paling sedikit adalah 1.500 buah $(16,67 \%)$. Harga rata-rata durian per buah adalah Rp.5.500 dengan harga termahal yakni Rp.7.000 (31,82\%) dan termurah Rp. 4.000 $(18,18 \%)$. Untuk jumlah rata-rata daging durian yang akan di olah adalah sebanyak 225 $\mathrm{Kg}$ dengan jumlah terbanyak yakni $300 \mathrm{Kg}$ $(33,33 \%)$, dan yang paling sedikit adalah 150 $\mathrm{Kg}(16,67 \%)$. Sedangkan rata-rata untuk harga daging durian adalah sebesar Rp. 55.000/Kg dengan harga tertinggi yakni $\mathrm{Rp}$. 70.000/Kg $(31,82 \%)$ dan yang terendah adalah $\mathrm{Rp}$. $40.000 / \operatorname{Kg}(18,18 \%)$.

Tabel 6. Penggunaan Bahan Baku yang digunakan Per Proses Produksi Lempuk Durian di Desa Selat baru Kecamatan Bantan KabupatenBengkalis, Tahun 2019

\begin{tabular}{|c|c|c|c|c|c|c|c|c|c|}
\hline \multirow[t]{2}{*}{ No } & \multirow[t]{2}{*}{ Pengusaha } & \multicolumn{2}{|c|}{ Jumlah Durian } & \multicolumn{2}{|c|}{ Harga Durian } & \multicolumn{2}{|c|}{$\begin{array}{c}\text { Jumlah Daging } \\
\text { Durian }\end{array}$} & \multicolumn{2}{|c|}{$\begin{array}{l}\text { Harga Daging } \\
\text { Durian }\end{array}$} \\
\hline & & Buah & $\%$ & $\mathrm{Rp}$ & $\%$ & $\mathrm{Kg}$ & $\%$ & $\mathrm{Rp}$ & $\%$ \\
\hline 1 & Pengusaha 1 & 3.000 & 33,33 & 7.000 & 31,82 & 300 & 33,33 & 70.000 & 31,82 \\
\hline 2 & Pengusaha 2 & 2.700 & 30,00 & 6.000 & 27,27 & 270 & 30,00 & 60.000 & 27,27 \\
\hline 3 & Pengusaha 3 & 1.800 & 20,00 & 4.000 & 18,18 & 180 & 20,00 & 40.000 & 18,18 \\
\hline 4 & Pengusaha 4 & 1.500 & 16,67 & 5.000 & 22,73 & 150 & 16,67 & 50.000 & 22,73 \\
\hline \multicolumn{2}{|c|}{ Jumlah } & 9.000 & 100,00 & 22.000 & 100,00 & 900 & 100,00 & 220.000 & 100,00 \\
\hline \multicolumn{2}{|c|}{ Rata-Rata } & \multicolumn{2}{|c|}{2.250} & & & \multicolumn{2}{|c|}{225} & \multicolumn{2}{|c|}{55.000} \\
\hline \multicolumn{10}{|c|}{$\begin{array}{ll}\text { b. Bahan Penunjang } & \text { proses produksi lempuk durian, pengusaha } \\
\text { Selain menggunkan bahan baku, } & \begin{array}{l}\text { hanya menggunakan bahan tambahan berupa } \\
\text { gula sebagai pemanis sekaligus menjadi }\end{array} \\
\text { diperlukan juga input lain sebagai bahan } & \text { pengawet untuk lempuk. } \\
\text { tambahan (bahan penunjang) untuk } & \end{array}$} \\
\hline
\end{tabular}
menyempurnakan hasil produksi. Dalam

Tabel 7. Pengadaan Bahan Baku dan Penunjang dalam Usaha Agroindustri Lempuk Durian di Desa Selatbaru Kecamatan Bantan Kabupaten Bengkalis, Tahun 2019.

\begin{tabular}{|c|c|c|c|c|c|c|c|c|c|c|c|c|}
\hline $\mathrm{N}$ & \multirow[t]{2}{*}{ Uraian } & \multirow[t]{2}{*}{ Satuan } & \multicolumn{8}{|c|}{ Pengusaha $(\mathrm{P})$} & \multirow{2}{*}{$\begin{array}{c}\text { jum } \\
\text { lah }\end{array}$} & \multirow{2}{*}{$\begin{array}{l}\text { Rata- } \\
\text { Rata }\end{array}$} \\
\hline $\mathrm{o}$ & & & $\mathrm{P} 1$ & $\%$ & $\mathrm{P} 2$ & $\%$ & P3 & $\%$ & $\mathrm{P} 4$ & $\%$ & & \\
\hline A & Bahan Baku & & & & & & & & & & & \\
\hline 1. & $\begin{array}{l}\text { Daging } \\
\text { Durian }\end{array}$ & $\mathrm{Kg}$ & 300 & 33,33 & 270 & 30,00 & 180 & 20,00 & 150 & 16,67 & 900 & 225 \\
\hline $\mathrm{B}$ & \multicolumn{12}{|c|}{ Bahan Penunjang } \\
\hline 1. & Gula & $\mathrm{Kg}$ & 75 & 33,33 & 68 & 30,00 & 45 & 20,00 & 38 & 16,67 & 225 & 56,25 \\
\hline 2. & Kayu Bakar & Ikat & 0 & 0,00 & 60 & 33,33 & 60 & 33,33 & 60 & 33,33 & 180 & 45 \\
\hline 3. & Plastik Packiı & & & & & & & & & & & \\
\hline & -150 gram & $\mathrm{Kg}$ & 1 & 25,00 & 1 & 25,00 & 1 & 25,00 & 1 & 25,00 & 4 & 1 \\
\hline & -200 gram & $\mathrm{Kg}$ & 2 & 25,00 & 2 & 25,00 & 2 & 25,00 & 2 & 25,00 & 8 & 2 \\
\hline & -250 gram & $\mathrm{Kg}$ & 2 & 25,00 & 2 & 25,00 & 2 & 25,00 & 2 & 25,00 & 8 & 2 \\
\hline & -400 gram & $\mathrm{Kg}$ & 1 & 25,00 & 1 & 25,00 & 0 & 0,00 & 2 & 50,00 & 4 & 1 \\
\hline & -500 gram & $\mathrm{Kg}$ & 2 & 28,57 & 2 & 28,57 & 2 & 28,57 & 1 & 14,29 & 7 & 1,75 \\
\hline & $-1 \mathrm{Kg}$ & $\mathrm{Kg}$ & 2 & 40,00 & 1 & 20,00 & 1 & 20,00 & 1 & 20,00 & 5 & 1,25 \\
\hline 4. & Upih & Ikat & 17 & 36,17 & 13 & 27,66 & 10 & 21,28 & 7 & 14,89 & 47 & 11,75 \\
\hline 5. & Tali & Gulungan & 1 & 25,00 & 1 & 25,00 & 1 & 25,00 & 1 & 25,00 & 4 & 1 \\
\hline 6. & Label & Rim & 1 & 25,00 & 1 & 25,00 & 1 & 25,00 & 1 & 25,00 & 4 & 1 \\
\hline 7. & Isolasi & Gulungan & 3 & 30,00 & 3 & 30,00 & 2 & 20,00 & 2 & 20,00 & 10 & 2,5 \\
\hline 8. & Solar & Liter & 1 & 5,56 & 16 & 88,89 & 1 & 5,56 & 0 & 0,00 & 18 & 4,5 \\
\hline 9. & Gas & Tabung & 20 & 58,82 & 6 & 17,65 & 4 & 11,76 & 4 & 11,76 & 34 & 8,5 \\
\hline
\end{tabular}


Lempuk yang diproduksi dijamin tidak mengandung bahan pengawet buatan, karena lempuk yang diolah memang benar-benar daging durian dengan gula. Hal ini dilakukan para pengusaha agar hasil produksi mereka tetap terjaga kualitasnya.

Bahan penunjang yang digunakan adalah gula dan bahan pendukung yang mendukung proses pembuatan lempuk durian seperti: kayu bakar,solar, plastik packing, isolasi, gas, dan upih. Bahan pendukung dapat dijumpai di toko-toko terdekat di sekitaran wilayah agroindustri sehingga mempermudah pengusaha dalam melengkapinya. Untuk lebih jelasnya dapat dilihat pada Tabel 7 . Berdasarkan Tabel 7, bahan penunjang yang paling besar porsinya adalah penggunaan gula dengan rata-rata penggunaan sebanyak 56,25 $\mathrm{Kg}$ dengan penggunaan terbanyak $75 \mathrm{Kg}$ $(33,33 \%)$ dan yang paling sedikit adalah $38 \mathrm{Kg}$ $(16,67 \%)$. Bahan baku daging durian merupakan proporsi yang terbesar jika dibandingan dengan bahan lainnya. Banyaknya bahan baku juga mempengaruhi jumlah penggunaan bahan penunjang pada usaha lempuk durian tersebut. Semakin banyak penggunaan bahan baku maka semakin banyak pula jumlah penggunaanbahan penunjang, hal ini juga berpengaruh terhadap besarnya biaya yang dikeluarkan.

\section{c. Penggunaan Tenaga Kerja}

Tenaga kerja yang digunakan dalam agroindustri lempuk durian diperlukan untuk mengerjakan proses pembukaan durian, pemisahan biji dan daging durian, penimbangan, pengadukan, pendinginan, dan pengemasan. Secara rinci penggunaan tenaga kerja pada usaha agroindustri lempuk durian dapat dilihat pada Tabel 8.

Tabel 8. Rata-rata Jumlah Penggunaan Tenaga Kerja Berdasarkan Tahapan Pekerjaan per Proses Produksi Usaha Agroindustri Lempuk Durian di Desa Selatbaru Kecamatan Bantan Kabupaten Bengkalis, Tahun 2019.

\begin{tabular}{|c|c|c|c|c|c|c|c|c|c|c|}
\hline \multirow{2}{*}{$\begin{array}{l}\mathrm{N} \\
\mathrm{o}\end{array}$} & \multirow[t]{2}{*}{ Tahapan Produksi } & \multicolumn{8}{|c|}{ Hari Orang Kerja (HOK) } & \multirow{2}{*}{$\begin{array}{l}\text { Rata- } \\
\text { Rata }\end{array}$} \\
\hline & & P1 & $\%$ & $\mathrm{P} 2$ & $\%$ & P3 & $\%$ & P4 & $\%$ & \\
\hline 1. & $\begin{array}{l}\text { Pembukaan buah } \\
\text { durian }\end{array}$ & 0,50 & 4,60 & 0,50 & 5,41 & 0,50 & 9,52 & 0,50 & 9,52 & 0,50 \\
\hline 2. & $\begin{array}{l}\text { Pemisahan biji } \\
\text { dan daging }\end{array}$ & 1,13 & 10,34 & 1,13 & 12,16 & 0,50 & 9,52 & 0,50 & 9,52 & 0,81 \\
\hline 3. & Penimbangan & 0,13 & 1,15 & 0,13 & 1,35 & 0,13 & 2,38 & 0,13 & 2,38 & 0,13 \\
\hline 4. & $\begin{array}{l}\text { Pemasakan } \\
\text { (Pengadukan) }\end{array}$ & 7,50 & 68,97 & 6,75 & 72,97 & 3,00 & 57,14 & 2,50 & 47,62 & 4,93 \\
\hline 5. & Penyusunan & 0,13 & 1,15 & 0,13 & 1,35 & 0,13 & 2,38 & 0,13 & 2,38 & 0,13 \\
\hline 6. & Pengemasan & 1,50 & 13,79 & 0,63 & 6,76 & 1,00 & 49,05 & 1,50 & 28,57 & 1,16 \\
\hline & Jumlah & 10,88 & 100,00 & 9,25 & 100,00 & 5,25 & 100,00 & 5,25 & 100,00 & 7,66 \\
\hline & Rata-Rata & \multicolumn{2}{|c|}{1,81} & \multicolumn{2}{|c|}{1.54} & \multicolumn{2}{|c|}{0,88} & \multicolumn{2}{|c|}{0,88} & 1,27 \\
\hline
\end{tabular}
pengusaha agroindustri lempuk durian mengalokasikan tenaga kerja sebanyak 1,27 HOK. Rata-rata penggunaan tenaga kerja terbanyak pada saat pemasakan (pengadukan) sedangkan yang terendah adalah penimbangan dan penyusunan.

\section{d. Teknologi Pengolahan}

Peralatan yang digunakan dalam usaha agroindustri lempuk durian semi modern. Pengusaha menggunakan alat seperti mesin pemisah biji dan mesin pengadukan. Semua peralatan tersebut diperoleh dari daerah masing-masing. Alat yang paling banyak digunakan adalah baskom dengan rata-rata plastik. Baskom paling banyak digunakan karena alat tersebut merupakan alat yang digunakan untuk meletakkan daging durian maupun lempuk.

\section{e. Proses Produksi}

Teknologi produksi adalah suatu kegiatan yang dilakukan untuk menghasilkan produksi lempuk durian. Waktu yang paling lama digunakan adalah untuk proses pemasakan (pengadukan), hal ini dikarenakan pada proses inilah yang nantinya akan menentukan hasil maksimal. Kegiatan proses produksi secara rinci dapat dilihat pada Gambar 1. 


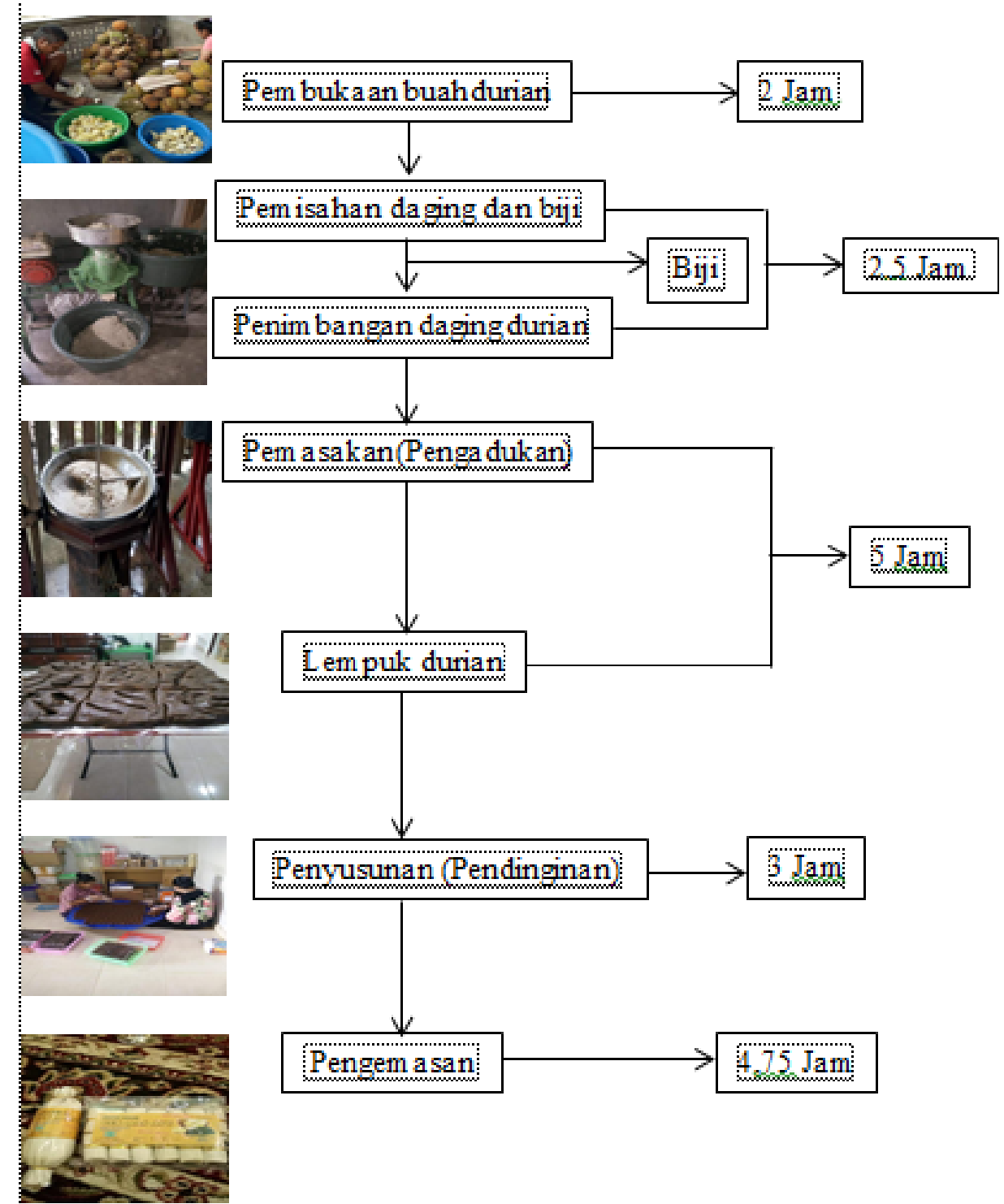

Gambar 1. Alur Proses Produksi Lempuk Durian di Desa Selatbaru Kecamatan Bantan Kabupaten Bengkalis.

Biaya Produksi, Pendapatan, Efisiensi Usaha dan Nilai Tambah Agroindustri Lempuk Durian

a. Biaya Produksi

Biaya produksi untuk menghasilkan lempuk durian terdiri dari biaya tetap dan biaya variabel. Biaya tetap dalam usaha agroindustri lempuk durian terdiri dari biaya penyusutan alat, biaya listrik, dan upah tenaga kerja. Biaya variabel terdiri dari bahan baku dan bahan bahan penunjang. Adapun biaya produksi yang di maksud dalam penelitian ini adalah seluruh biaya yang dikeluarkan dalam proses produksi agroindustri lempuk durian dapat dilihat pada Tabel 9.

Berdasarkan Tabel 9 menunjukkan bahwa biaya produksi dalam pengolahan durian menjadi lempuk sebesar Rp 15.861.138 per proses produksi. Bahan baku daging durian merupakan biaya variabel tertinggi yaitu $\mathrm{Rp}$ $12.375 .000(78,02 \%)$ dan biaya tertinggi kedua adalah biaya tenaga kerja (HOK) pada biaya tetap sebesar Rp 1.941.250. (12,08\%). Sementara itu, biaya terendah pada bahan penunjang yakni plastik packing ukuran 150 gram yakni sebesar Rp 10.000 (0,06\%).

\section{b. Pendapatan}

Pendapatan dalam usaha agroindustri lempuk durian meliputi pendapatan kotor dan pendapatan bersih. Pendapatan kotor usaha agroindustri lempuk durian adalah sebagian nilai produksi total usaha dalam jangka waktu tertentu baik yang dijual ataupun yang tidak dijual. Pendapatan kotor yang di terima oleh pengusaha sebesar Rp 26.937.500. Pendapatan 
bersih yang diterima oleh pengusaha sebesar Rp 11.051.367.

\section{c. Efisiensi}

Efisiensi usaha agroindustri lempuk durian diperoleh dengan membandingkan pendapatan kotor yang diperoleh dengan total biaya yang dikeluarkan pada setiap proses produksi. Layak atau tidaknya suatu usaha untuk dijalankan dan memberi keuntungan bagi pengusaha dilihat dari efisiensinya.
Rata-rata efisiensi agroindustri lempuk durian sebesar 1,70. Dari nilai RCR tersebut, kegiatan agroindustri lempuk durian sangat layak untuk dilanjutkan, karena dapat memberikan keuntungan. Berdasarkan hasil penelitian Gustiawan dkk (2015), secara finansial menunjukkan bahwa usaha lempuk durian layak untuk diusahakan.

Tabel 9. Rata-Rata Distribusi Perhitungan Biaya Per Proses Produksi padaUsaha Lempuk Durian di Desa Selatbaru Kecamatan BantanKabupaten Bengkalis, Tahun 2019.

\begin{tabular}{|c|c|c|c|c|c|c|}
\hline No & Uraian & Satuan & Jumlah & Harga (Rp) & Nilai (Rp) & $\begin{array}{l}\text { Persentase } \\
(\%)\end{array}$ \\
\hline I & Biaya Variabel & & & & & \\
\hline \multirow[t]{2}{*}{ A } & Bahan Baku & & & & 12.375 .000 & 78,02 \\
\hline & 1.Daging durian & $\mathrm{Kg}$ & 225 & 55.000 & 12.375 .000 & 78,02 \\
\hline \multirow[t]{16}{*}{ B } & Bahan Penunjang & & & & 1.542 .500 & 9,73 \\
\hline & 1.Gula & $\mathrm{Kg}$ & 56,25 & 14.000 & 787.500 & 4,96 \\
\hline & 2.Kayu Bakar & Ikat & 45 & 3.000 & 135.000 & 0,85 \\
\hline & 3.Plastik Packing & & & & & \\
\hline & -150 gram & $\mathrm{Kg}$ & 1 & 10.000 & 10.000 & 0,06 \\
\hline & -200 gram & $\mathrm{Kg}$ & 2 & 12.000 & 24.000 & 0,15 \\
\hline & -250 gram & $\mathrm{Kg}$ & 2 & 15.000 & 30.000 & 0,19 \\
\hline & -400 gram & $\mathrm{Kg}$ & 1 & 15.000 & 15.000 & 0,09 \\
\hline & -500 gram & $\mathrm{Kg}$ & 1,75 & 20.000 & 35.000 & 0,22 \\
\hline & $-1 \mathrm{Kg}$ & $\mathrm{Kg}$ & 1,25 & 22.000 & 27.500 & 0,17 \\
\hline & 4.Upih & Ikat & 11,75 & 3.000 & 35.250 & 0,22 \\
\hline & 5.Tali & Gulungan & 1 & 28.000 & 28.000 & 0,18 \\
\hline & 6.Label & Rim & 1 & 160.000 & 160.000 & 1,01 \\
\hline & 7.Isolasi & Gulungan & 2,5 & 7.000 & 17.500 & 0,11 \\
\hline & 8.Solar & Liter & 4,5 & 7.500 & 33.750 & 0,21 \\
\hline & 9.Gas & Tabung & 8,5 & 24.000 & 204.000 & 1,28 \\
\hline \multicolumn{2}{|c|}{ Jumlah Biaya Variabel } & & & & 13.917.500 & 87,75 \\
\hline \multirow[t]{4}{*}{ II } & Biaya Tetap & & & & & \\
\hline & 1.Penyusutan & & & & 22.238 & 0,14 \\
\hline & 2.Listrik & Watt & & & $5.149,75$ & 0,03 \\
\hline & 3.Tenaga Kerja & HOK & 8,29 & & 1.941 .250 & 12,08 \\
\hline \multicolumn{2}{|c|}{ Jumlah Biaya Tetap } & & & & 1.943 .638 & 12,25 \\
\hline \multicolumn{2}{|c|}{ Total } & & & & 15.861.138 & 100,00 \\
\hline \multicolumn{2}{|c|}{ Produksi } & $\mathrm{Kg}$ & 187,50 & & & \\
\hline \multicolumn{2}{|c|}{ Pendapatan Kotor } & $\mathrm{Rp}$ & & & 26.937 .500 & \\
\hline \multicolumn{2}{|c|}{ Pendapatan Bersih } & $\mathrm{Rp}$ & & & 11.051 .367 & \\
\hline \multicolumn{2}{|c|}{ Efisiensi (RCR) } & & & & 1,70 & \\
\hline
\end{tabular}

\section{d. Nilai Tambah}

Meningkatkan nilai tambah merupakan tujuan dari kegiatan agroindustri. Keuntungan yang diperoleh oleh pengusaha dan imbalan jasa dari alokasi tenaga kerja dapat juga diartikan sebagai nilai tambah. Teknologi dan perlakuan yang digunakan dalam kegiatan agroindustri akan mempengaruhi besar kecilnya nilai tambah yang akan diperoleh. Nilai tambah dari kegiatan usaha agroindustri lempuk durian dapat dilihat pada Tabel 10.
Tabel 10 menjelaskan rata-rata nilai tambah agroindustri lempuk durian menghasilkan output lempuk sebanyak 187,50 $\mathrm{Kg}$, dengan rata-rata penggunaan input sebanyak 225,00 Kg. Faktor konversi 0,83 diperoleh dari hasil output dibagi dengan input, artinya banyaknya output yang dapat dihasilkan dari satu-satuan input. Sumbangan input lain dalam penelitian ini hanya diperoleh dari biaya pemakaian input lain operasional untuk pengusaha 1 (satu), pengusaha 2 (dua), pengusaha 3 (tiga), dan pengusaha 4 (empat) 
sebesar $\mathrm{Rp} 7.842 / \mathrm{Kg}$ produk, Rp 7.902/Kg produk, $\mathrm{Rp} 8.477 / \mathrm{Kg}$ produk, dan $\mathrm{Rp} 9.280 / \mathrm{Kg}$ produk dengan rata-rata $\mathrm{Rp} 8.375 / \mathrm{Kg}$.

Nilai tambah yang diperoleh dari pengolahan durian per proses produksi menjadi lempuk, untuk pengusaha 1 (satu), pengusaha 2 (dua), pengusaha 3 (tiga), dan pengusaha 4 (empat) dengan rasio nilai tambah sebesar $\mathrm{Rp}$ $55.491 / \mathrm{Kg}(0,42 \%), \mathrm{Rp} 65.431 / \mathrm{Kg}(0,49 \%)$, $\mathrm{Rp} \quad 51.523 / \mathrm{Kg} \quad(0,51 \%)$, dan $\mathrm{Rp} 32.020$ $(0,35 \%)$ dengan rata-rata $\mathrm{Rp} 51.016 / \mathrm{Kg}$ $(0,44 \%)$.
Artinya dengan harga bahan baku $\mathrm{Rp}$ $70.000 / \mathrm{kg}$, Rp 60.000/Kg, Rp 40.000/Kg, dan $\mathrm{Rp} 50.000 / \mathrm{Kg}$ menghasilkan nilai tambah sebesar Rp 55.491/Kg, Rp 65.431 /Kg, Rp $51.523 / \mathrm{Kg}$, dan Rp 32.020/Kg.

Nilai tambah yang semakin besar atas produk pertanian dapat berperan bagi peningkatan pertumbuhan ekonomi, dan tentunya dapat berimplikasi pada peningkatan lapangan usaha dan pendapatan masyarakat, yang selanjutnya dalam jangka panjang dapat meningkatkan kesejahteraan masyarakat (Kementerian Keuangan 2012).

Tabel 10. Nilai Tambah Metode Hayami pada Agroindustri Lempuk Durian di Desa Selatbaru Kecamatan Bantan, Tahun 2019.

\begin{tabular}{|c|c|c|c|c|c|c|c|}
\hline \multirow{2}{*}{ No } & \multirow{2}{*}{ Variabel } & \multicolumn{4}{|c|}{ Nilai } & \multirow{2}{*}{ Jumlah } & \multirow{2}{*}{$\begin{array}{l}\text { Rata- } \\
\text { Rata }\end{array}$} \\
\hline & & P1 & $\mathrm{P} 2$ & $\mathrm{P} 3$ & $\mathrm{P} 4$ & & \\
\hline \multicolumn{8}{|c|}{ I. Output, Input, dan Harga } \\
\hline 1. & Output (Kg) & 250 & 225 & 150 & 125 & 750 & 187,50 \\
\hline 2. & Input $(\mathrm{Kg})$ & 300 & 270 & 180 & 150 & 900 & 225,00 \\
\hline 3. & Tenaga kerja (HOK) & 11,5 & 9,88 & 5,88 & 5,88 & 33,14 & 8,29 \\
\hline 4. & Faktor konversi & 0,83 & 0,83 & 0,83 & 0,83 & 3,33 & 0,83 \\
\hline 5. & $\begin{array}{l}\text { Koefisien Tenaga } \\
\text { Keria }(\mathrm{HOK} / \mathrm{Kg})\end{array}$ & 0,04 & 0,04 & 0,03 & 0,04 & 0,15 & 0,04 \\
\hline 6. & Harga output $(\mathrm{Kg})$ & 160.000 & 160.000 & 120.000 & 110.000 & 550.000 & 137.50 \\
\hline 7. & $\begin{array}{l}\text { Upah tenaga kerja } \\
\text { (Rp/HOK) }\end{array}$ & 209.565 & 197.368 & 336.735 & 249.150 & 992.818 & $\begin{array}{r}248.20 \\
5\end{array}$ \\
\hline \multicolumn{8}{|c|}{ II. Pendapatan dan Keuntungan } \\
\hline 8. & $\begin{array}{l}\text { Harga bahan baku } \\
(\mathrm{Rp} / \mathrm{Kg})\end{array}$ & 70.000 & 60.000 & 40.000 & 50.000 & 220.000 & 55.000 \\
\hline 9. & $\begin{array}{l}\text { Sumbangan input lain } \\
\text { (Rp/Kg output) }\end{array}$ & 7.842 & 7.902 & 8.477 & 9.280 & 33.501 & 8.375 \\
\hline 10. & $\begin{array}{l}\text { Nilai output } \\
\text { (Rp/Kg/Output) }\end{array}$ & 133.333 & 133.333 & 99.600 & 91.300 & 457.567 & $\begin{array}{r}114.39 \\
2\end{array}$ \\
\hline \multirow[t]{2}{*}{11.} & $\begin{array}{l}\text { a.Nilai tambah } \\
(\mathrm{Rp} / \mathrm{Kg})\end{array}$ & 55.491 & 65.431 & 51.123 & 32.020 & 204.066 & 51.016 \\
\hline & $\begin{array}{l}\text { b. Rasio nilai tambah } \\
(\%)\end{array}$ & 0,42 & 0,49 & 0,51 & 0,35 & 1,77 & 0,44 \\
\hline \multirow[t]{2}{*}{12.} & $\begin{array}{l}\text { a.Pendapatan } \mathrm{TK} \\
\text { langsung }(\mathrm{Rp} / \mathrm{Kg})\end{array}$ & 8.033 & 7.222 & 11.000 & 9.767 & 36.022 & 9.006 \\
\hline & $\begin{array}{l}\text { b.Pangsa tenaga kerja } \\
(\%)\end{array}$ & 0,14 & 0,11 & 0,22 & 0,31 & 0,78 & 0,19 \\
\hline \multirow[t]{2}{*}{13.} & $\begin{array}{l}\text { a.Keuntungan } \\
(\mathrm{Rp} / \mathrm{Kg})\end{array}$ & 47.458 & 58.209 & 40.123 & 22.253 & 168.043 & 42.010 \\
\hline & $\begin{array}{l}\text { b.Tingkat } \\
\text { Keuntungan }(\%)\end{array}$ & 0,86 & 0,89 & 0,78 & 0,69 & 3,22 & 0,81 \\
\hline \multicolumn{8}{|c|}{ III. Balas Jasa Pemilik Faktor Produksi } \\
\hline \multirow[t]{4}{*}{14.} & Margin $(\mathrm{Rp} / \mathrm{Kg})$ & 63.333 & 73,333 & 59.600 & 41.300 & 237.567 & 59.391 \\
\hline & $\begin{array}{l}\text { a. Pendapatan tenaga } \\
\text { kerja }(\%)\end{array}$ & 0,13 & 0,10 & 0,18 & 0,24 & 0,65 & 0,16 \\
\hline & $\begin{array}{l}\text { b.Sumbangan input } \\
\text { lain }(\%)\end{array}$ & 0,12 & 0,11 & 0,14 & 0,22 & 0,60 & 0,15 \\
\hline & $\begin{array}{l}\text { c.Keuntungan } \\
\text { pengusaha }(\%)\end{array}$ & 0,75 & 0,79 & 0,67 & 0,54 & 2,76 & 0,69 \\
\hline
\end{tabular}

Pengolahan komoditas durian menjadi lempuk durian sangat bermanfaat bagi pelaku 
usaha. Akrige et al (1997), kegiatan pengolahan produk pertanian menjadi produk turunannya dapat meningkatkan nilai tambah, meningkatkan keuntungan. Menurut Anderson dan Hanselka (2009), meningkatkan umur simpan mengingat komoditas pertanian bersifat perishable mudah rusak.

\section{Pemasaran Lempuk Durian}

Memperoleh keuntungan merupakan tujuan dari menjalankan suatu usaha. Setiap pengusaha untuk mencapai tujuan tersebut maka salah satu yang menjadi kegiatan pokok yang dilakukan yaitu pemasaran. Saluran pemasaran lempuk durian terdiri dari dua saluran, saluran 1 dimulai dari pengusaha ke pedagang pengecer ke konsumen akhir, saluran 2 dari pengusaha langsung ke konsumen akhir. Disajikan pada Gambar 2.
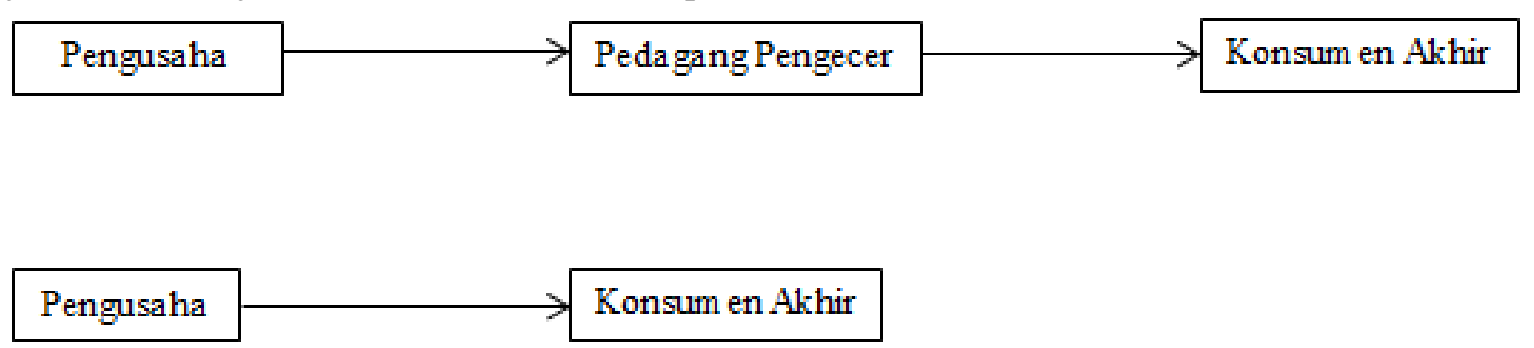

Gambar 2. Saluran Pemasaran Lempuk Durian di Desa Selatbaru Kecamatan Bantan, Tahun 2019

Berdasarkan hasil penelitian Agustina (2015) di Kabupaten Bengkalis, industri lempuk durian terdapat tiga pola saluran distribusi, yaitu: (1). Produsen-konsumen (zero level channel). (2). Produsen-pengecerkonsumen (one level channel). (3). Produsenpengumpul pengecer-konsumen (two level channel).

\section{KESIMPULAN}

1. Karakteristik pengusaha lempuk durian di Desa Selatbaru Kecamatan Bantan Kabupaten Bengkalis dengan rata-rata berumur 46,75 tahun (47 orang), lama pendidikan setara SMA, pengalaman berusaha 13,75 (14 tahun) dan jumlah tanggungan keluarga 4,25 (5 jiwa). Profil usaha agroindustri lempuk durian berbentuk skala industri kecil dengan tujuan usaha untuk meningkatkan pendapatan dan kesejahteraan keluarga.

2. Rata-rata penggunaan bahan baku berupa daging durian sebesar 225kg/proses produksi, rata-rata penggunaan bahan penunjang berupa : gula $56,25 \mathrm{~kg} /$ proses produksi, kayu bakar 45 ikat, plastik packing (ukuran 150 gram $1 \mathrm{~kg}, 200$ gram 2 $\mathrm{kg}, 250$ gram $2 \mathrm{~kg}, 400$ gram $1 \mathrm{~kg}, 500$ gram $1,75 \mathrm{~kg}$, dan ukuran $1 \mathrm{~kg}$ sebesar 1,25 $\mathrm{kg}$, penggunaan upih sebanyak 11,75 ikat, tali 1 gulung, label $1 \mathrm{rim}$, isolasi 2,5 gulungan, solar 4,5 liter, menghabiskan 8,5 tabung gas ukuran $3 \mathrm{~kg}$. Kemudian untuk rata-rata penggunaan biaya tetap:

penyusutan sebesar $\mathrm{Rp}$ 22.238/proses produksi, biaya listrik sebesar $\mathrm{Rp}$ 5.149,75/proses produksi, dan upah untuk tenaga kerja sebesar Rp 1.916.138/proses produksi.

3. Rata-rata biaya produksi sebesar $\mathrm{Rp}$ 15.886.133/proses produksi, pendapatan kotor sebesar Rp 26.937.500/proses produksi dan pendapatan bersih sebesar Rp 11.051.367/proses produksi. Nilai RCR sebesar 1,70, nilai tambah agroindustri olahan durian sebesar Rp 51.016.

4. Pemasaran produk pada usaha agroindustri lempuk durian memiliki dua saluran pemasaran yakni: (1) Produsen ke pedagang pengecer dan dari pengecer ke konsumen akhir. (2) Produsen ke konsumen akhir.

\section{DAFTAR PUSTAKA}

Agustina, K. 2015. Analisis Strategi Bersaing Industri Kecil Makanan Tradisional (Kasus Pada Usaha Lempuk Durian Di Kabupaten Bengkalis). Jom Fisip, 1 (2): 1-14.

Akrige, J., Downey, D., Boehlje, K., Harling, F., Barnard. Baker, T. 1997. Food System 21 Gearing Up for the New Millenium in Agricultural Input Industries. West Lafayette: Purdue 
University Cooperative Extension Service.

Aldy, S., Prayoga Suryadarma. 2019. Peningkatan Nilai Tambah Durian Afkir melalui Produksi Dodol Durian di Kuala Selangor Malaysia. Jurnal Pusat Inovasi Masyarakat, 1 (1): 92-98

Anderson, DP., Hanselka, D. 2009. Adding Value to Agricultural Products. Texas A\&M University. Retrieved from: http://hdl.handle.net/1969.1/86940.

Dewi, KH., Nusril., Helmiyetti., Rosalina, Y., Sarumpaet, P. 2013. Analisis Nilai Tambah Kopi Teripang Jahe Pra Campur Saset. Kajian Masalah Sosial Ekonomi Pertaian dan Agribinis. Jurnal Agrisep, 12 (2): 209-216.

Feng, J., Wang, Y., Yi, X., Yang, W., He, X. 2016. Phenolics From Durian Exert Pronounced NO Inhibitory and Antioxidant Activities. Journal of Agricultural and Food Chemistry, 64 (21): 4273-4279.

Gustiawan, I., Yusmini., dan S. Hadi. 2015. Analisis Finansial Usaha Agroindustri Lempuk Durian (Studi Kasus: Agroindustri Lempuk Durian Elvia Di Desa Bantan Tengah Kecamatan Bantan Kabupaten Bengkalis). Jom Faperta, 2(2): 1-12.

Hernanto, F. 1996. Ilmu Usahatani. Penebar Swadaya, Jakarta.

Hernanto, F. 1991. Ilmu Usahatani. Penebar Swadaya, Bandung.

Kantor Desa Selatbaru. 2019. Nama-Nama Pengusaha Agroindustri Olahan Durian. Desa Selatbaru, Kabupaten Bengkalis.

Kementrian Keuangan RI. 2012. Laporan Kajian Nilai Tambah Produk Pertanian. Jakarta, Indonesia

Rachmat, M. 2013. Perspektif Pengembangan Industri Pengolahan Pangan di Indonesia. Diversifikasi Pangan dan Transformasi Pembangunan Pertanian. Badan Penelitian dan Pengembangan Pertanian.

Soekartawi. 2002. Analisis Usahatani. Universitas Indonesia, Jakarta.

Soekartawi. 2000. Pengantar Agroindustri. Edisi Pertama. Penerbit PT. Raja Grafindo Persada, Jakarta.

Soekartawi. 1995. Analisis Usahatani. UI Press, Jakarta.
Sudiyono, A. 2001. Pemasaran Pertanian. Universitas Muhammadiyah Malang, Malang. 
